\title{
Embedding Crowdfunding Structure in Islamic Venture Capital for SMEs Development
}

\author{
Fauzul Hanif Noor Athief \\ Universitas Muhammadiyah Surakarta \\ email: fhn208@ums.ac.id
}

\begin{abstract}
SMEs that play significant role in Indonesia economy still suffer from financial constraint. Even though government provides big support to open finance access for SMEs, there are still more than half are not supported by sufficient access of financing. This paper investigates the possible financing methods that can be used by SMEs by examining its positive and negative aspects along with the shariah view on it. Since there are limitations that have to be removed, we propose new scheme of financing suits best for Indonesia SMEs based on the venture capital design by embedding crowdfunding structure and the Islamic element in it. This paper also proposes new possible exit strategy for the scheme in order to benefit all parties involved.
\end{abstract}

Keywords: SME; Venture Capital; Crowdfunding; Shariah; Indonesia

\begin{abstract}
Abstrak: UKM memiliki peran penting dalam perekonomian Indonesia yang masih mengalami kendala keuangan. Meskipun pemerintah memberikan dukungan besar untuk membuka akses keuangan untuk UKM, masih ada lebih dari setengah yang tidak didukung oleh akses pembiayaan yang memadai. Kajian ini meneliti kemungkinan metode pembiayaan yang dapat digunakan oleh UKM dengan memeriksa aspek positif dan negatifnya disertai dengan pandangan syariah atas permasalahan ini. Karena ada keterbatasan yang harus dihilangkan pada model-model pembiayaan, maka kami mengusulkan skema baru pembiayaan yang terbaik untuk UKM Indonesia berdasarkan desain modal ventura dengan menanamkan struktur crowdfunding dan elemen Islami di dalamnya. Penelitian ini juga mengusulkan kemungkinan strategi keluar baru untuk skema tersebut agar bermanfaat bagi semua pihak yang terlibat
\end{abstract}

Kata Kunci: UKM; Modal usaha; Crowdfunding; Syariah; Indonesia

Economica: Jurnal Ekonomi Islam - Volume 10, Nomor 1 (2019) 


\section{Introduction}

Employment in a country has always been important discussion since long time ago. The reason is simply because individual person needs income to maintain their daily live. Through a job, people can generate income and hence fulfill their basic necessities of house, clothing and foods. The better their job, the more a person is paid for it and thus increasing their power of purchase. Purchasing any goods or services will be in the end counts to the GDP of a country. However, employment absorbent remains as big problem in many jurisdictions, including Indonesia. Compared to other neighboring regions, Indonesia stands as the second higher unemployment rate.

Figure 1. Unemployment rate across some ASEAN regions.

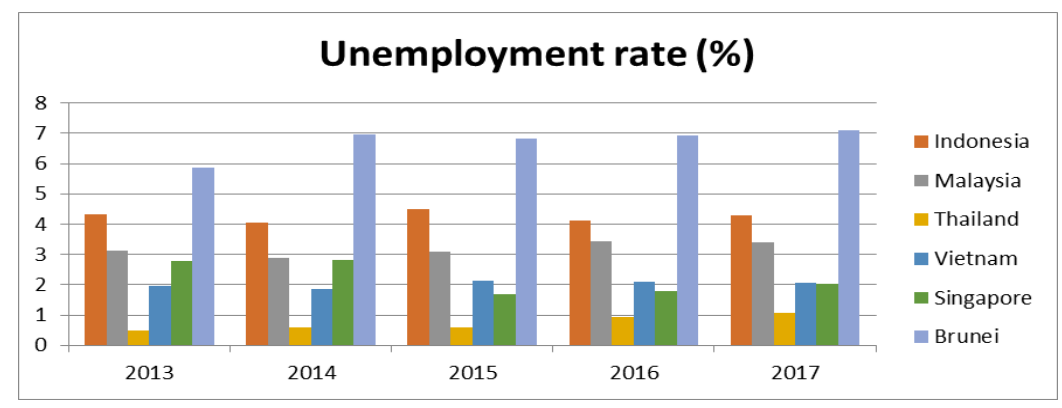

Source: World Development Indicator (WDI) by World Bank

This low employment rate leads into bigger trouble in the society which is the intense increase in criminal cases. Those unemployed people would have financial hardship which triggers them to commit crime in order to remove that hardship. Interestingly, the criminal associated with the unemployment status of a person is more related to offences involving material gain such as robbery, theft and sort of those stuffs. Meanwhile, the other types of crime such as violence and vandalism are rarely committed by them (Farrington, Gallagher, Morley, Ledger, \& West, 1986). The other researchers also found out similar conclusion where unemployment in 
general triggers people to commit crime (see Raphael \& Winter-Ebmer, 2001; Ward \& Carmichael, 2001). Even a quite new research on this topic also recorded same conclusion that unemployment is one of the factor for committing crime with the material-driven motivation (Phillips \& Land, 2012).

However, creating employment opportunity is not an easy task. Handing over such heavy duty only to the government will end up in unwanted result. Instead, we need a person with the entrepreneur enthusiasm to open up new business and therefore absorb the available labor. In this case, what government can do is creating the opportunity for such people. Fortunately, while Global Entrepreneurship Monitor (GEM) asserts that many entrepreneurs around the world are opportunity driven, the report produced by GEM shows that index of Indonesia's government support on entrepreneur reaches averagely 3.8 out of 5 . In the same time, the report also shows that $45 \%$ of Indonesia citizen aged from $18-64$ believe that there is opportunity to start business ${ }^{1}$.

Since entrepreneurs are in the nucleus of this activity, the focus must be highlighted on them. It is well known that more often than not, entrepreneur start their business from small scale by creating any Small and Medium Sized Enterprises (SMEs). Unfortunately, a mere idea of business along with courage within the entrepreneur spirit is insufficient. Most of business needs capital to grow which becomes the hindrance for any entrepreneur take their business off from the ground or even to only start it. Here, numerous SMEs get difficulties of funding. This difficulty had been recorded since before 2000s. A research done by Pissarides (1999) for example finds that among many obstacles faced by SMEs, credit constraint becomes the most important

\footnotetext{
1 Based on the country profile provided by GEM. The details can be seen in its official website http://www.gemconsortium.org/country-profile/70
}

Economica: Jurnal Ekonomi Islam - Volume 10, Nomor 1 (2019) http://journal.walisongo.ac.id/index.php/economica 
one. In 2006, another research done by Beck, Demirgüç-Kunt, Laeven, \& Maksimovic (2006) using huge data compiled by The World Business Environment Survey find that small firms always tend to find more difficulty in obtaining financing compared to the medium and the large companies. They also documented that the growth constraint resulted from financing has twice effect for small enterprise compared to the big companies (see figure 2). The researches came afterward still show that financing problem remains as the most significant hindrance until recent year (see for example Kamran Sherazi et al., 2013; Wang, 2016).

Figure 2. The effect of various obstacles on growth constraint of business entities from different sizes. The growth constraint is estimated using regression on firm growth to the obstacles.

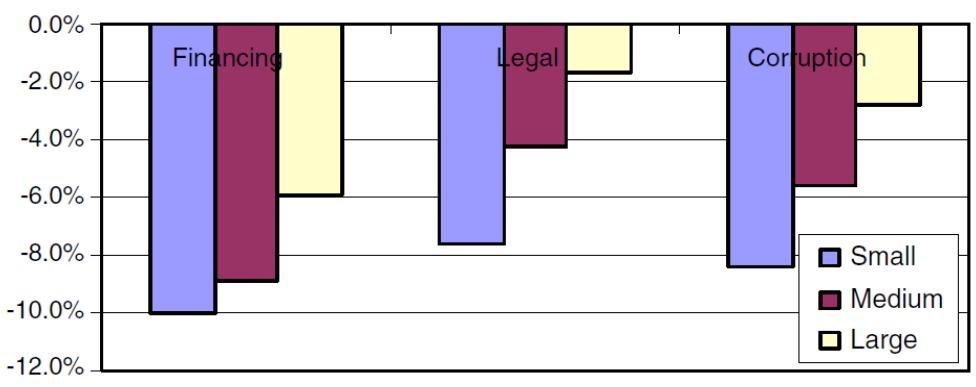

Source: Beck and Demirguc-Kunt (2006).

From short explanation above, it can be understood that in order to boost the economy, SMEs directed by passionate entrepreneur could be one of its engine. However, in order to spur SMEs, the obstacle has to be eliminated. This paper tries to make suggestion on how could the financing problem of SMEs removed by avoiding any additional problem such as limited fund source, information asymmetry and agency problem. On top of that, we seek to find the best solution which complies with shariah requirements. 
Embedding Crowdfunding Structure in Islamic Venture Capital ...

\section{Literature Review}

\section{SMEs' Role for Indonesia's Growth}

Business idea is something that anybody can have a think about it. However, it is only entrepreneur who has big courage to bring such idea into reality. Any of these business ideas will always start small before eventually take important role in the industry. It is therefore the entrepreneur will run a business in the form of small or medium enterprises (SMEs).

In the case of Indonesia, these SMEs play very significant role in building the country. Ministry of Cooperative and SME has recorded SMEs' contribution in absorbing and increasing Indonesia's economy. In the Ministry's blueprint of financing for SMEs (Ministry of Cooperative and SMEIndonesia, 2015), it is mentioned there that SMEs take $99.98 \%$ of total business units in Indonesia with the total of 57.90 million units at 2013. In addition to that, there has been an increase trend of the figure of SMEs unit from 2008 until 2013 by $2.4 \%$ averagely. SMEs' significant role can be also seen from its share on GDP which reaches up to 59\% of total GDP. SMEs in Indonesia were also able to make very high labor absorption on 2012. It was up to $99.99 \%$ or equal to 107 million of total labor were absorbed whereas only $3.1 \%$ of labor were absorbed by big companies. Apart from it, SMEs also contribute about $55 \%$ to national investment.

The study between SMEs and growth nexus has also been recorded by researchers. Tambunan (2008) for example finds that despite of the increasing income level in Indonesia, SMEs were able to survive and yet contribute to the annual GDP growth of $2 \%$ average annually from 20032006. Far apart from Indonesia, Muritala, Awolaja, \& Bako (2012) also finds that SME brings impact for economic growth in Nigeria. However, we do not deny that in a more sophisticated study conducted by Beck, Asli, \& Levine, (2005) finds that the positive relationship between SME and economic growth is not really evident. Based on the estimation using OLS regressions,

Economica: Jurnal Ekonomi Islam - Volume 10, Nomor 1 (2019)

http://journal.walisongo.ac.id/index.php/economica 
the positive relationship stands where size of the SME sector affects economic growth. Nevertheless, the relationship becomes insignificant the endogeneity is controlled in the equation.

Despite all of SMEs importance mentioned above, not all people can easily indulge in the entrepreneurship area since it necessitates some basic requirements including ideas and funding. Courage is not mentioned here because it must be shaped as the entrepreneur's character from the very beginning. Luckily, the first requirement can be easily found nowadays from a full digital access in the tip finger of every people. People who found that wedding photography shows high demand in their region while only few market players there might utilize internet and get some browsing for photography techniques. Others who found that certain ice cream currently has a hiking trend of sale can learn the way to make it. When fruit juice is enjoyed by the citizen in the district an entrepreneur live in, he also can easily learn best ingredient and the way to make it from any website sources. Thus, full digital access really helps people in learning how to do basic business properly.

However, there remains funding as one obstacle that considered as the most hindrance in establishing a business compared to the other SMEs success determinant including marketing strategy, technological resources, information access, business plan and government support (Jasra, Khan, Hunjra, Rehman, \& Azam, 2011). Since SMEs are not the type of big size scale of company and mostly are established for only few years, many formal financial institutions feel reluctant to extend their financing to those SMEs (Beck et al., 2006). More often than not, SMEs especially in country having poor institutions uses mostly internal financing and merely tap in to the formal bank financing (Beck, Demirgüç-Kunt, \& Maksimovic, 2008). CarbóValverde, Rodríguez-Fernández, \& Udell (2008) also found that since these SMEs mostly have the credit constraint problem (about one-third of France's SMEs), most of those constrained firm has to recourse to the trade credit. 
In the case of Indonesia, The Ministry of Cooperative and SME reported on their five years planning blueprint that financial institutions tend to extend their financing to medium level businesses compared to the small and micro businesses. This will be a problem for the context of Indonesia since the SMEs are mostly constituted by micro enterprises (Ministry of Cooperative and SME Indonesia, 2015). The good news is that the total financing extended to SMEs by the formal institutions keeps increasing yearly by $13.63 \%$ in average (see figure 3 ). However, Bank Indonesia as the central bank of the country also reported that there are up to $60 \%-70 \%$ of SMEs do not have proper access to the financing. While some internal factors contribute to this figure, some external factors such as lack of coordination between the stakeholders of SMEs including the financial institutions affect the condition (Amidzic, Massara, \& Mialou, 2014; Sari et al., 2015). The fact that most of SMEs at Indonesia suffers financial problem reflects that financial institutions are not motivated to provide enhanced financial product that effectively and innovatively cater the needs of SMEs (Tambunan, 2008).

Figure 3. Total credit of SMEs in segregated bank types. The value shown is in trillion Rupiah nominal.

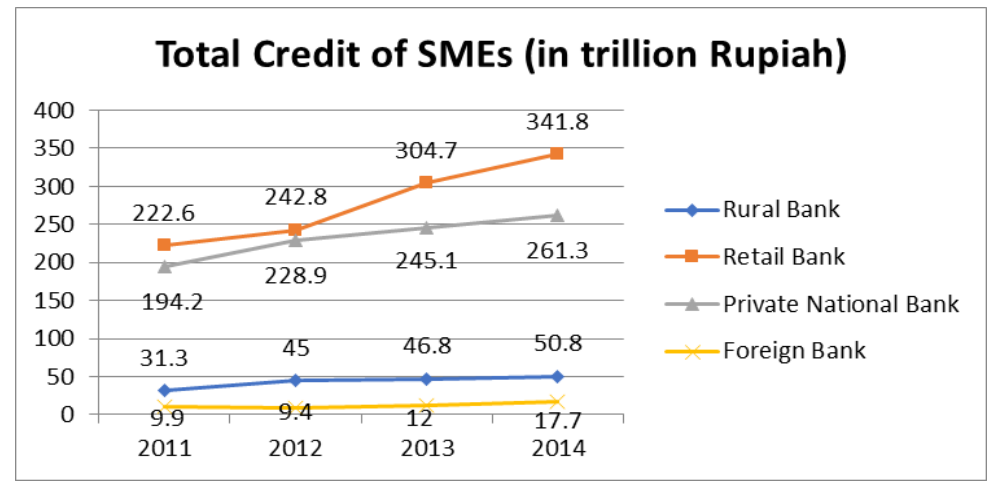

Soure: Bank Indonesia, 2015.

Economica: Jurnal Ekonomi Islam - Volume 10, Nomor 1 (2019)

http://journal.walisongo.ac.id/index.php/economica 
For SMEs, relying on bank as the source of funding is one of difficult options. First, from the SMEs perspective as fund user, the cost would tend to be higher compared to any regular financing. This is simply because the formula of the profit the bank expects to earn is as the following:

\section{Profit = cost of deposit + overhead cost + inflation premium + credit risk premium}

While the first three variables will be indifferent with regards of fund users, the last variable which is credit risk premium would vary highly according to the fund users' profile. In this case, fund users with good track records will have less cost and the opposite is true. Meanwhile, SMEs are industry which records are yet to be established and hence increase the cost on the credit risk premium variable as its compensation. The high cost due to the high credit risk premium will be difficult to be covered by SMEs annual revenue.

From the bank's perspective, channeling the fund to SMEs is considered as high risk investment when it is done through instruments which demand the fund users to pay sum of money periodically (De la Torre, Pería, \& Schmukler, 2008). Failure of payment will increase the NPF of the bank and increase their management effort. In the downturn economic situation, the high number of NPF will exacerbate banks condition. In addition to that, bank also will be exposed to asset and liability mismatch when the funding is done through pure equity model. Bank's balance sheet is however comprised mostly of short term savings. When the bank is forced to purchase any equity of SMEs, it means they add to their liability a very long term item. Having short term asset in one hand and the long term liability in the other side will disrupt the flow of business in the bank.

As the result, most of the SMEs forced to use private fund from internal funding in form of the equity. For those who have family with good financial 
condition might also rely on their assets. SMEs also usually try to seek funding from their close colleagues or business relative to assist their financial constraint. However, there are cases when the fund sourced from family and colleagues is not enough to bring the business off the ground. This makes the business stuck at the same level and grow very slowly. This is especially for the case of SMEs in Indonesia where most of it are considered as micro businesses with location resides at the village where rich family, colleagues with good financial condition and supportive business relatives are rarely found.

\section{Methods}

Since we try to figure out new possible way of financing for SMEs, the research here would be a descriptive research relying on the facts of current available financing methods. Some evaluation and elaboration would be done for the available method from the economic perspective. As this paper also emphasizes on the shariah principle, examination of the financing method from shariah perspective will be carried out. The result of evaluation on benefit and limitation from the existing financing method will next be used to develop new scheme of financing. The new scheme then structured from the very beginning of the fund flow until the end of the venture. Any possible risk mitigation on the new scheme will be included in the discussion as well.

\section{Result}

\section{The Available Financing Methods}

\section{Simple Method}

For the SMEs, getting funding is one of the corner stone in their business. Almost all of the SMEs will start the business by utilizing what the owners currently have in the pocket. They put the money in the business as the initial capital for the business to commence. Most of the part of profit 
generated from the business will be reinvested again at the venture in order to make the business growing while the rest could be used for owners' individual consumption. When it is a type of family business, each of family members will contribute to the capital which is considered as the equity. Whether it is individual or family business, the expansion of such business will rely on the owners themselves. When they are out of money, then the business has to stop at that particular point.

Apart from owners own money, SMEs owners are also able to rely to the external informal fund. One of the convenient sources is the loan from the family. This external borrowing is relatively low cost and at the same time has very flexible maturity time. Using such funding will give the owners more room to make innovation in the business. Family's support can also come in any financial back up, including donation. High income parent and family members usually extend such aid as the tangible evidence of their moral support. Unfortunately, not all SMEs owners are blessed with this kind of family. In the same time such support has its limit.

Another external source of fund that can be utilized is the bank's financing. However, either banks or SMEs feel reluctant to make use of the fund because bank's financing has negative effect for both sides as explained above. For the case of Indonesia, the government set regulations to help opening financial access for SMEs. One of the most influential regulation is Bank Indonesia Enactment (Peraturan Bank Indonesia) 14/22/PBI/2012 on Financing by Retail Banks and Technical Support in Developing SMEs where it is clearly stipulated there that, "Retail bank is obliged to extend credits or financing for SMEs." In addition to that, Bank Indonesia also states that starting from 2015, the SMEs financing to total financing ratio should not be less than 5\%. Despite of this high support Bank Indonesia still reports that there are $60 \%-70 \%$ of SMEs have no access to the financing (LPPI \& Indonesia, 2015). 
In any of three options above, SMEs encounter new problem raised from the funding. Owners' individual money has very low limit, family member also faces some problem of limit although better from the previous option, while bank financing will come with high cost for SMEs.

\section{Crowdfunding}

The development of technology especially in the field of communication brings massive change in the way people interact. Not only a day to day common interaction, business interaction and financial dealings are also highly affected by the technology. While people in the past day make trading and sale through physical market, nowadays they can do it while sitting in their own home. While previously there exists mediator between the first hand producers of the good to the end user, now people can optimize their trading by avoiding mediator and hence making a peer to peer business.

A peer to peer business does not only come in the form of trading. Instead, the way people make investment can be done through the same model in this era by using crowdfunding platform. Crowdfunding itself is a practice of raising money from vast amount of people via internet where the proceeds could be used for business or donation purposes. For the business purpose, the contributors will be offered by various type of payback according to the type of crowdfunding. A reward-based crowdfunding provides the contributor promised reward as agreed in the beginning such as products, privilege usage and many others. Meanwhile, an equity crowdfunding gives the contributors shares of the company in exchange for the money pledged.

Crowdfunding is very useful platform when it is utilized to its optimum usage. This is because majority of Indonesia citizen are not well acquainted with the capital market as it is always perceived having sophisticated contracts. Thus, shaping specific capital market for the purpose of SMEs would still find difficulties in helping SMEs to grow. For the contributors,

Economica: Jurnal Ekonomi Islam - Volume 10, Nomor 1 (2019) 
capital market is sought as complex system. Meanwhile, the management within the SMEs and the human resource runs the business of SMEs is not yet equipped with sufficient knowledge to embrace this type of capital market. Crowdfunding for SMEs also provides big advantage by breaking the limit of the fund due to its characteristic where the platform gives equal opportunity for all people to contribute. From investors' perspective, crowdfunding is very user-friendly platform where no specific IT background is required. People who are familiar with e-commerce are most likely to be able to interact in this platform. Despite of the easiness in term of access and understanding, crowdfunding has only small share of total fintech based transaction in Indonesia (see figure 5).

Figure 5. Crowdfunding to total share of fintech based services on 2017

\section{Percentage Distribution of the Indonesian Fintech} System

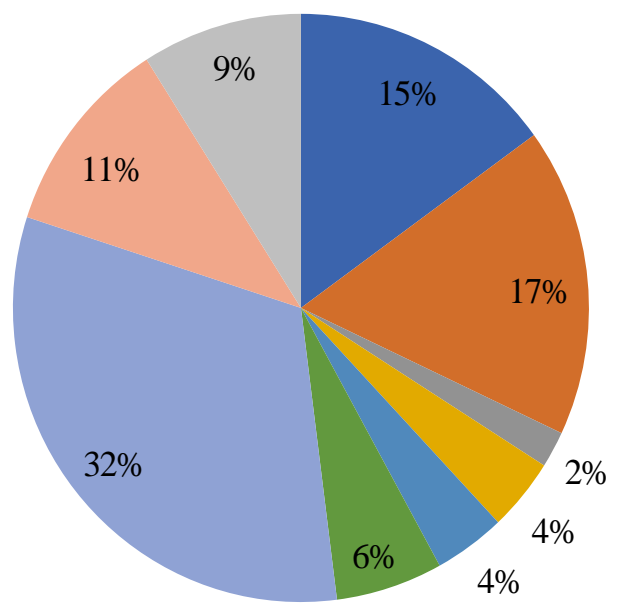

$$
\begin{aligned}
& \text { - Lending } \\
& \text { Comparison } \\
& \text { Personal Finance } \\
& \text { Investment } \\
& \text { Cryptocurrency } \\
& \text { Accounting } \\
& \text { Payment } \\
& \text { Postal Service } \\
& \text { Crowdfunding }
\end{aligned}
$$

Source: New Fintech Report Highlights Indonesia's Untapped Digital Finance Opportunity as it is adapted from ethiscrowd.com 
Using this platform, the business owner no needs to be wealthy enough to fund his own business, nor does he need resourceful family to support the sustainability of the business. Wide range coverage of potential investors can be attracted easily to the venture by simply providing business description and share it through any available social media forum. It saves the time, energy and cost for SMEs by cutting all efforts required in approaching investors individually. On top of that, the period needed to collect the fund is relatively far shorter compared to simple method of financing.

Just like any other financial instruments and platform, shariah has its own judgment on any practice to be considered as permissible or prohibited. The permissibility of transaction needs to follow the Islamic principle laid down by this religion which has been elaborated by number of jurists. Crowdfunding is unique platform where the backers (term for the fund contributor) can know directly the type of business an entrepreneur runs by reading the description provided. Meanwhile, business owners can also make direct proposal to many potential investors without involving additional layers of mediator except those crowdfunding platform managers. From here, we can see that crowdfunding is a mere contribution, collection and use of fund by all parties involved. Thus, shariah allows such transaction.

Going deeper to the types of crowdfunding, reward-based crowdfunding is basically an agreement that backers will receive rewards commensurate to their contribution. This transaction can be considered as type of charity embedded with one side promise to give any goods or service after reaching certain progress in the business. Jurists from Maliki school agree that in case the promise involves financial lose once it is breached, then the promise considered as binding and thus such scheme is shariah compliant. AAOIFI (2015) also has standard pertaining to this matter and stipulates that such promise can be binding legally. In the same time, equity crowdfunding also can be considered as shariah compliant instrument since it is simply investing money in a venture in exchange of shares commensurate the sum

Economica: Jurnal Ekonomi Islam - Volume 10, Nomor 1 (2019) 
of money pledged. However, its compliance is subject to condition where no preferred stock is issued for the backers.

Despite of the usefulness of crowdfunding, there are limitations raised from its characteristics when it is applied for SMEs especially for equity based crowdfunding. The most important thing to notice is that SMEs and any other start-ups are businesses in very nascent stage. It takes very long time for such entity to ripe for the backers (investors) to be able to harvest fruits from their investment. Meanwhile, backers have to fully understand that their contribution is in the form of equity where the dividend is not necessarily distributed once in a year or even for 4-5 years. Most of the retained earnings will be usually reinvested to the venture in order to accelerate the growth of the business while leaving nothing for the dividend.

Unfortunately, for such long term project, none of those investors are involved in directional or managerial affairs within the business. This is the reason why crowdfunding is highly criticized by the potential of fraud caused from information asymmetry (Agrawal, Catalini, \& Goldfarb, 2013). The problem of information asymmetry itself emerges from the very beginning of the campaign. Most of crowdfunding campaign will use attractive words and phrase to gain attention and ensure backers that the business is worthy and promising. Some equity crowdfunding platform has managed to eliminate this risk entirely by doing thorough investigation and due diligence before any company can make their campaign. However, no monitoring is provided once the campaign is over. The backers themselves cannot make proper monitoring on the business since it requires specific knowledge on the business as well as in the industry he invests in.

\section{Islamic Venture Capital (IVC)}

Prior to the existence of crowdfunding, SMEs encounter high difficulty in obtaining fund to finance their business. SMEs have to approach bank and convince them that the business is prosperous. In other case, some SMEs 
have to struggle in the commencement of their business by using owners' entire fund to sustain the business until the point that the business has good enough track record for the bank to believe in. However, as it is presented above, banks rarely pay attention to SMEs.

Here, venture capital comes as the solution of restricted funding for SMEs or any nascent businesses. The modern emergence of venture capital itself can be traced back to the first half of $20^{\text {th }}$ century. This financial institution is type of financing which rely mostly on the usage of equity. Venture capital firms (VCs) typically receives fund from external sources such as investment banks, pension funds, insurance companies and many institutional investors. Those types of companies are characterized by highrisk long term profile investors and thus suit the risky venture such as SMEs.

The most noticeable feature of venture capital is that it does not only offer support in monetary form, but also in managerial and technical matters. When a VC decides to finance a business, it usually provides the money in exchange with the control within the firm to eliminate any possibility of information asymmetry. However, many owners are actually reluctant to have second opinion stands on the equal power in directing the business. Even though business owners tend to dislike this involvement, VCs actually have the same goal with the owners, that is to grow the business successfully since VCs cannot afford to lose money they invest in. Thus, we see opposite opinion of owners' perspective that VCs actually have big benefits of helping business to make relation, seeking proper market for them, attracting more possible investors, convincing other business players and many other benefits (Hochberg, Jungqvist, \& Lu, 2007).

From investors' perspective, one of the high risk element which is information asymmetry in the SMEs business can be eliminated through venture capital. Since venture capital has special right to act as directing opinion and can be involved in the managerial affair, there will be no secret can be kept from the company. When the business performs not very well,

Economica: Jurnal Ekonomi Islam - Volume 10, Nomor 1 (2019) 
VCs can be directly informed and then step in to take necessary measures. It is also hard for SMEs company to keep some valuable assets out from the VCs supervision. While there is perception that agency problem might arise as the result of this scheme, it can be argued that the problem has no underlying reasons. First, VCs put their fund in the business with very high potential loss. Secondly, VCs has no favorable exit option unless the business grows and prospers which make the value of the shares increase dramatically. Third, business owners also have their capital in venture which makes them in the same position with VCs where no exit option is available unless the business succeeds. Thus, the interest of both parties here aligned.

From the SMEs perspective, guided by VCs can be so beneficial. There are countless of new start-up and SMEs that suffer from poor legal advice apart being having insufficient funding. The managers of these businesses also usually have inadequate knowledge of the market in which they operate. More often than not, they also suffer the lack of understanding on how to make good financial structure within company (Fagura, 2015). Working aside the VCs give SMEs the advices on their problem without having to hire professionals for it.

While VCs in essence do investment financing model, it is done through various schemes. VCs channel their money to the business and will claim their profit accordingly based on the share of equity they hold. In the same time, VCs also exposed to very big chance of loss. Thus we can say that in general, the fundamental principle of venture capital resembles the notion of profit loss sharing in Islam. However, people nowadays tend to be risk averse and do risk shifting. As long as the profit can be claimed without risking any asset, then they would go for it. Hence, many instruments are created to fulfill such desire. In venture capital, there are plenty ways to extend the finance apart from the equity purchase (investment). Some of other common used instruments are convertible debt and preferred shares. 
Khan \& Al-rifai (2000) found that there are nonshariah compliant instruments used by VCs. Elsiefy (2014) has made glimpse investigation on the instruments used by VCs in general and specifically used by VCs in MENA region. He concludes that for equity financing which basically done by purchasing part of the business project is shariah compliant since it reflects the core of profit-loss sharing. Most often than not, investors require condition on their funding by the privilege of right and protection above other shares. This privilege is the character of preferred stock which has been decided as non-shariah compliant by Islamic jurists. There is also an instrument called convertible debt in which investors contribute to the company by extending loan that can be converted into equity once the business nourishes which needs deeper investigation. Elsiefy (2014) did not make clear judgment in this particular instrument and open broader discussion for jurists. However, in the case that the convertible debt entails interest at agreed rate, the instrument is considered as not permissible. Another instrument is warrant which gives its holder privilege to exercise the right of purchasing shares at a specified price. Alsayyed (2009) states that for the case of call warrant, Islamic Instrument Study Group (IISG) passed a resolution saying that the use of call warrant is permissible with the condition that the underlying asset of that warrant is also shariah compliant.

The focusing point on the discussion is that VCs product has to be modified to some extent in order to make it compliance with shariah principles. In addition to that, IVCs are also bounded to make investment only on businesses that does not violate the rule of shariah.

While venture capital eliminates the possibility of information asymmetry between investors and the business owners, it has limit source of fund in the other hand. Those big time investors as the primary source of fund for VCs might have internal financial problem that hinder them to provide more fund to the VCs. Secondly, since these sources of fund also act on the behalf of other party, the cost charged to the VCs will be high since 
they have to make profit out of it. VCs then will charge higher cost to the SMEs as the consequence.

\section{Discussion}

\section{Enhancement of Islamic Venture Capital (IVC)}

From the types of financing above, all of it has limitation to help developing the SMEs. Using crowdfunding solely leads to high information asymmetry to the investors even though it is low cost and brings no limit to the source of fund at the same time. In the other hand, using only venture capital will expose SMEs to very high cost although the information asymmetry can be mitigated by using the right as the manager under this scheme. Both types of financing strike each other's weakness which forces us to solve both problems simultaneously. Thus, taking positive characteristic from each type of financing is hopefully can be the solution for SMEs financing problem.

To decide which type will be the bottom foundation of the financing method, we shall take into consideration that based on the press release by Financial Services Authority of Indonesia (OJK) at 2017, Indonesia's financial literacy stood at $29.66 \%$. Even though this number is $7.18 \%$ higher compared to the previous survey in 2013 , there are still more than two-third of Indonesia citizen are not familiar with the financial matters ${ }^{2}$. This figure also shows that out of millions SMEs unit in Indonesia, there are only some of it has capable human resource in management and financial dealings. In this regard, venture capital suits best for Indonesia SMEs by providing its expertise on finance and managerial affairs. On top of that, venture capital with their broad range of connection and link can further help Indonesia SMEs by getting the owner in contact with related businessman or introduce

2 OJK Press Release number SP/07/DKNS/OJK/I/2017 
the business to the industry association. This is because presumably VCs have better quality relationships and hence enjoy more influential networks positions (Hochberg et al., 2007). In short, venture capital is capable for covering SMEs necessities.

Since venture capital fits the character of Indonesia SMEs, the financing model proposed here will be based on it. While Sanrego (2017) proposes hybrid model of mutual fund and venture capital to help SMEs, here we use crowdfunding characteristic as the addition structure in the financing scheme. The venture capital will take the equity form as it is the safest scheme from shariah critics. The additional structure of crowdfunding is done for some purposes. First, it is done to eliminate the risk associated with each type of financing mentioned above. Second, the financial literacy level announced by 0JK implies that a sophisticated financing method will not be familiar for the citizen. However, crowdfunding has been successfully introduced for its simple system. Third, since financial inclusion is one of Indonesia's agenda, the proposed structure here is also to ensure the financing platform can reach vast number of users.

\section{General Design of Enhanced IVC}

As this scheme optimizes the existence of crowdfunding, it allows any interested individual to contribute to the investment. As the initial procedure, SMEs have to approach IVC along with its proposal for the desired business. Once approved, IVC will publish it on its website in the form of crowdfunding campaign. Just like the regular crowdfunding, IVC might deduct sum of money as the fee for this service. Apart from it, IVC also provides investment from its own money. The collected fund will be then channeled to the respective businesses as desired by the investors (see Figure 6). 
Fauzul Hanif Noor Athief

Figure 6. Investment Flow

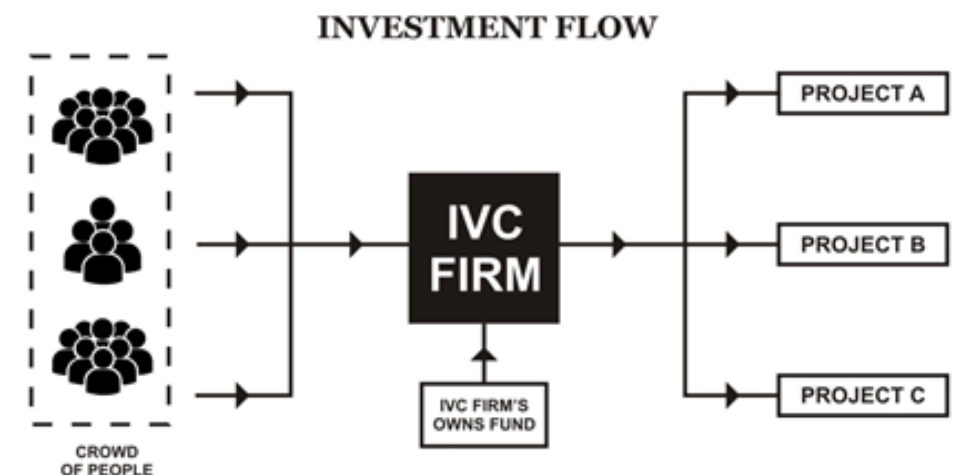

Figure 7. Asset Position After Investment

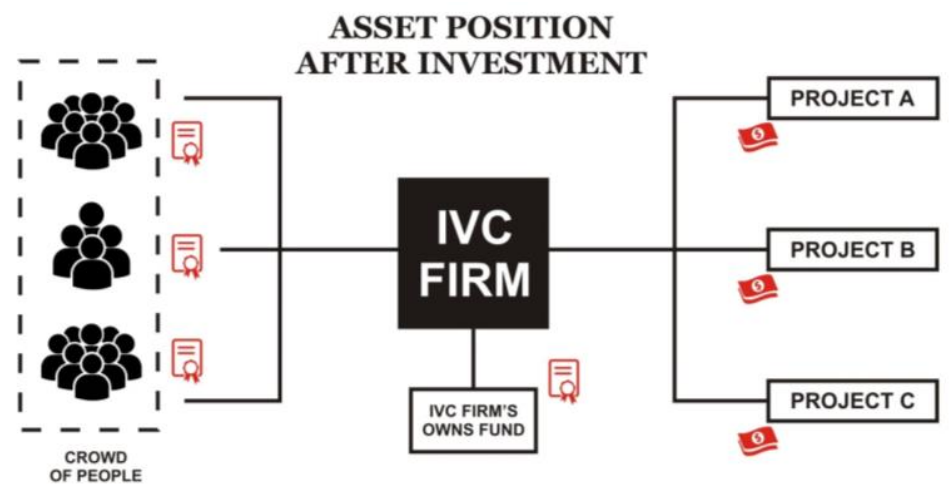

Once the fund is successfully channeled to the SMEs, each of the investors will receive proof of claim on the business' equity according to the sum of money invested. In the regular equity crowdfunding, SMEs will leave the crowdfunding platform provided by the company once the campaign is over and the fund is received by the business. Crowdfunding platform providers will have no right nor obligation on any event occurred between 
the investors and SMEs afterwards. Here, the case will be different for this scheme (see Figure 7).

This IVC will continue the crowdfunding platform after the campaign by keeping the investors informed for any progress. However, it is the SMEs that obliged to perform the duty on making information up to date for the investors since it will be burdensome when the IVC itself do it. Here, the relation is only between IVC and SMEs as well as between SMEs and the investors. For the relation between IVC and investors is that the initial provides update about the SMEs through their website.

Figure 8. Profit Disbursement

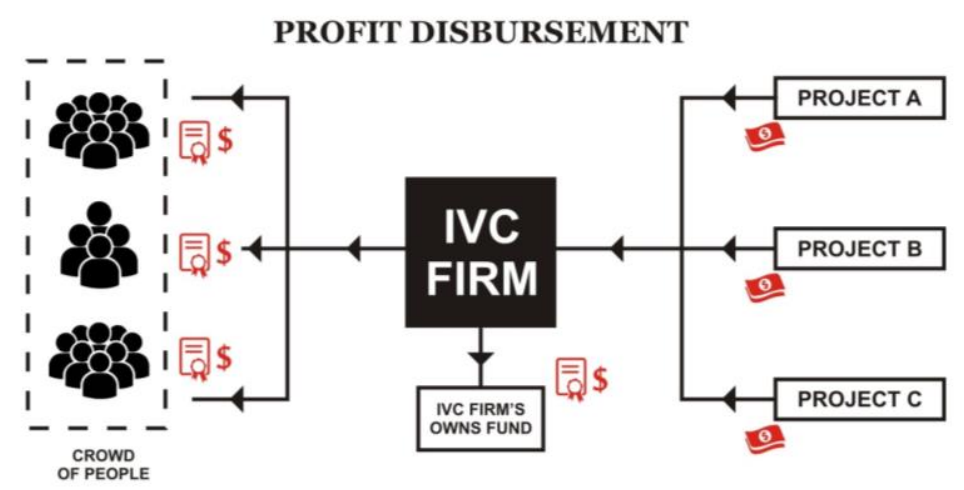

The business progress will keep going through the year after the campaign over and the fund channeled. Even though SMEs mostly do not distribute profit for any equity contributed to the venture, there could some exceptional cases. In this regard, the profit is distributed based on the contribution of equity accordingly. At this stage, IVC will have relation to the investors by distributing the profit. Investors still hold their certificate of partial business ownership while having profit comes to their pocket (see Figure 8).

Economica: Jurnal Ekonomi Islam - Volume 10, Nomor 1 (2019) 
Figure 9. Exit Strategy IPO, Merger and Acquisition

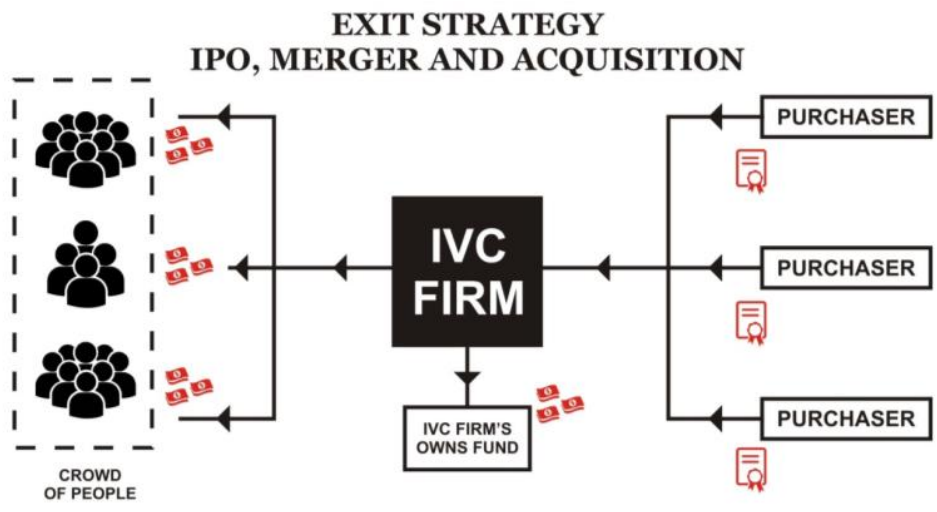

More often than not, there will be no profit distribution until the "exit" event comes through IPO or merger and acquisition (MA). This is why investing in SMEs and nascent business is very risky yet promising high profit in the same time. It takes years for a business to come into the stage where it is qualified to do IPO. During the IPO time, the value of share investors initially purchase will be multiplied several times. The spread between the investing price and sale price is the profit that investors gain. Once the share is sold, investors will receive the money and might leave the venture along with the profit they earned. Meanwhile, the purchaser will hold the equity that previously held by crowdfunding investors. IVC also receives its profit according to its investment. On top of that, IVC might require additional fee as the service it provides throughout the business of maintaining website for information update, service of profit distribution after IPO and more importantly the service of supervising the venture throughout the years. In case the exit is done through MA, the flow follows same path as it is in the IPO. The only different is that the purchaser will not be comprised of many entities or individuals. However, the eventual effect of profit distribution remains the same (see Figure 9). 
Embedding Crowdfunding Structure in Islamic Venture Capital ...

Figure 10. Exit Strategy Internal Market

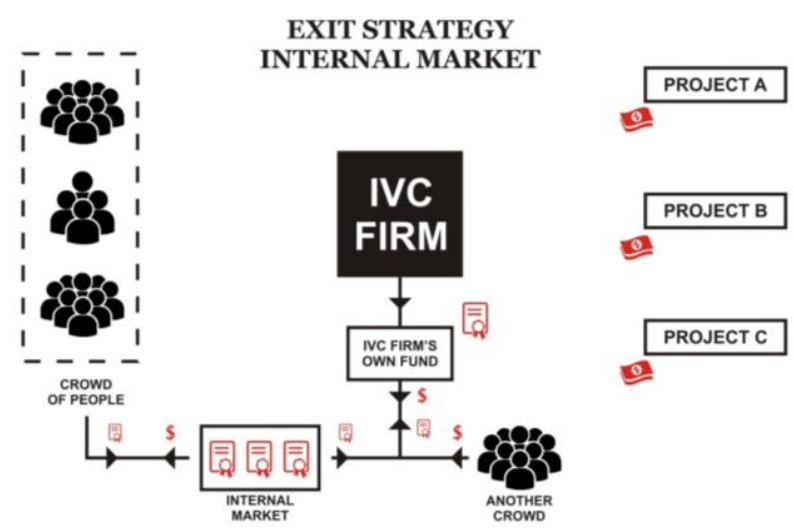

Exit event always become the important discussion on venture capital topic. No VCs wants to suffer loss by making exit without generating profit from their investment. However, there are countless write-off by VCs of their investment, meaning they walk away from the venture. The enhanced structure of the venture capital can provide additional exit options. This is in addition that the enhanced venture capital here is embedded by crowdfunding structure where the crowd of investors has to have specific exit strategy. Unlike equity crowdfunding which provides no exit except through formal purchase by other party, this financing scheme brings more benefit for both IVCs and investors. IVCs might establish internal market for the stocks held by crowdfunding investors.

This internal market serves as the place where people can sale their equity asset to other investors from crowd or even for the IVCs. The valuation of asset can be done by IVCs or other external expert by benchmarking it to similar business in the same industry or other mean of valuation. The sale price then announced by initial crowdfunding investors within the website platform provided by IVC. Once the price is announced, crowd can start buying it. It is important to be noted that market reacts according to the price set by the initial investors. When market feels the price

Economica: Jurnal Ekonomi Islam - Volume 10, Nomor 1 (2019) 
does not worth the business, they will abandon it and leave the initial investors holding the equity until undetermined time. In case that none from the crowd interested, IVC might negotiate the price for a lower nominal and hence purchase it for itself. During the sale and purchase of the equity through internal market, the business of SME will not be disturbed. This internal market can be considered as risk mitigation strategy that can be used to minimize the risk for investors and increase income for IVCs (see figure 10).

\section{Limitation}

Apart from the explanation above, there is limitation on the usage of this scheme. Indonesia has growing number of middle class people. However, only few of those people are aware about the high risk in this long term project. They might also do not fully understand about few options of exit available once they involved in such investment. Thus, although this scheme can open the investment access to all people, it has to be implemented gradually by restricting the investors to only certain people fulfilling requirements established by $0 \mathrm{JK}$. After more people being aware about the essence of investing in an SME projects, only then government can provide full access to the citizen without restriction. So far, this gradual implementation has been done by USA. The good news is that OJK will soon release the regulation on equity crowdfunding by August or September 2018.3 OJK not only has to deal with the gradual implementation. The establishment of internal market, the sale and purchase within it, valuation method of equity during the middle of growing business and many other aspects has to be well monitored by OJK.

\footnotetext{
${ }^{3}$ https://finance.detik.com/moneter/d-4114826/ojk-rilis-aturan-equitycrowdfunding-bulan-depan-apa-itu . Retrieved at 15 July 2018, 08.50 PM
} 
Embedding Crowdfunding Structure in Islamic Venture Capital ...

\section{Conclusion}

SMEs make high contribution to Indonesia economy by making high labor absorption and provide more than half of Indonesia's GDP. Going underneath of this fact, SMEs always find difficulty in financing their operation. Even though there is an increase trend of banks participation for SMEs, there are still more than one-third SMEs remains having no access to proper financial resource. Thus, there has to be solution for SMEs as the engine of economy to gain support in order to loose their financial constraint.

This paper successfully elaborates positive and negative element of the possible financing methods that SMEs might use in the modern day. First, the simple method is indeed the easiest way to obtain financing. However, it suffers from the very low limit on the source. Second, crowdfunding that emerges recently can remove the problem of limited source in classical method. Nevertheless, even though this method removes the aforementioned problem, it suffers from information asymmetry problem that inherits within the platform. Third, venture capital that has been relied mostly by SMEs and start ups can solve the problem of information asymmetry. Nonetheless, there is still possible limitation of primer fund source. We also examined the shariah compliance of all methods and find that there has to be some modifications for VCs to be considered as Islamic.

Since all of financing methods encounter problem that become the strength of another, a combination of the mentioned methods would be the solution. As the combination of the scheme, we suggest that venture capital embedded with crowdfunding structure suits best for Indonesia condition. Since the venture capital which takes the scheme of equity purchase and investment conforms the very core principle of profit loss sharing in Islam, we build the new scheme based on it. During the elaboration of this new scheme, we also demonstrate the additional exit strategy that would be beneficial for all parties involved.

Economica: Jurnal Ekonomi Islam - Volume 10, Nomor 1 (2019) 


\section{References}

AAOIFI. (2015). Shariah Standards. Manama, Kingdom of Bahrain: Dar AlMaiman.

Agrawal, A. K., Catalini, C., \& Goldfarb, A. (2013). Some Simple Economics of Crowdfunding. NBER WORKING PAPER SERIES, No. 19133.

Alsayyed, N. (2009). Shariah Parameters of Islamic Derivatives in Islamic Banking and Finance. International Shariah Research Academy for Islamic Finance.

Amidzic, G., Massara, A., \& Mialou, A. (2014). Assessing Countries' Financial Inclusion Standing - A New Composite Index. International Monetary Fund, WP/14/36(IMF Working Paper).

Beck, T., Asli, D.-K., \& Levine, R. (2005). SMEs, GROWTH, AND POVERTY. NBER WORKING PAPER SERIES, (Paper No. 11224).

Beck, T., Demirgüç-Kunt, A., Laeven, L., \& Maksimovic, V. (2006). The determinants of financing obstacles. Journal of International Money and Finance, 25(6), 932-952.

Beck, T., Demirgüç-Kunt, A., \& Maksimovic, V. (2008). Financing patterns around the world: Are small firms different? Journal of Financial Economics, 89(3), 467-487.

Carbó-Valverde, S., Rodríguez-Fernández, F., \& Udell, G. F. (2008). Bank lending, financing constraints and SME investment. Federal Reserve Bank of Chicago, Chicago, IL, (Working Paper, No. 2008-04).

De la Torre, A., Pería, M. S. M., \& Schmukler, S. L. (2008). Bank Involvement with SMEs: Beyond Relationship Lending. World Bank, 4649 (Policy Research Working Paper).

Elsiefy, E. (2014). Fundamental Requirements for Building an Islamic Venture Capital Model. Accounting and Finance Research, 3(1), 55-66.

Fagura, B. A. K. (2015). Structuring Islamic investments for venture capital opportunities, (February), 24-25.

Farrington, D. P., Gallagher, B., Morley, L., Ledger, R. J. S., \& West, D. J. (1986). Are There Any Successful Men from Criminogenic Backgrounds? The British Journal of Criminology, 26(4), 335-356. 
Hochberg, Y. V, Jungqvist, A. L., \& Lu, Y. (2007). Whom You Know Matters : Venture Capital Networks and Investment Performance * $†$ Johnson School of Management Whom You Know Matters: Venture Capital Networks and Investment Performance Abstract. The Journal of Finance, $\operatorname{LXII}(1)$.

Indonesia, K. K. dan U. K. dan M. R. (2015). Blueprint Pembiayaan Koperasi, Usaha Mikro, Kecil dan Menengah Tahun 2015-2019.

Jasra, J. M., Khan, M. A., Hunjra, A. I., Rehman, R. A. U., \& Azam, R.-I. (2011). Determinants of Business Success of Small and Medium Enterprise. International Journal of Business and Social Science, 2(20), 274-280.

Kamran Sherazi, S., Zubair Iqbal, M., Asif, M., \& Saad Hussain Shah, S. (2013). Obstacles to Small and Medium Enterprises in Pakistan. Principal Component Analysis Approach. Middle-East Journal of Scientific Research, 13(10), 1325-1334.

Khan, A., \& Al-rifai, T. (2000). The Role of Venture Capital in Contemporary Islamic Finance. 4th Harvard University Forum on Islamic Finance, 243250.

LPPI, \& Indonesia, B. (2015). Profil Bisnis Usaha Mikro, Kecil dan Menengah (Umkm). Bank Indoneisa.

Muritala, T. A., Awolaja, A. M., \& Bako, Y. A. (2012). Impact of Small and Medium Enterprises on Economic Growth and Development Impact of Small and Medium Enterprises on Economic Growth and Development. American Journal of Business and Management, 1(1), 18-22.

Phillips, J., \& Land, K. C. (2012). The link between unemployment and crime rate fluctuations: An analysis at the county, state, and national levels. Social Science Research, 41(3), 681-694.

Pissarides, F. (1999). Is Lack of Funds the Main Obstacle to Growth? EBRD'S Experience with Small- and Medium-Sized.Journal of Business Venturing, 14(5), 519-539.

Raphael, S., \& Winter-Ebmer, R. (2001). Identifying the Effect of Unemployment on Crime. The Journal of Law \& Economics, 44(1).

Sanrego, Y. D. (2017). The Role of Islamic Capital Market for Micro, Small and Medium Enterprises (MSMES) through Synergy of Mutual Fund and Venture Capital Institution. Journal of Islamic Monetary Economics and Finance, 3(1), 81-112.

Economica: Jurnal Ekonomi Islam - Volume 10, Nomor 1 (2019) 
Sari, Y. R., Manullang, N., Anas, T., Narjoko, D. A., Andre, S., Wini, P., Paramitha, F. (2015). Pemetaan dan Strategi Peningkatan Daya Saing UMKM dalam Menghadapi MEA 2015 dan Pasca MEA 2025. Working Paper Bank Indonesia, WP/9/2015.

Tambunan, T. (2008). SME development, economic growth, and government intervention in a developing country: The Indonesian story. Journal of International Entrepreneurship, 6(4), 147-167.

Wang, Y. (2016). What are the biggest obstacles to growth of SMEs in developing countries? - An empirical evidence from an enterprise survey. Borsa Istanbul Review, 16(3), 167-176.

Ward, R., \& Carmichael, F. (2001). Male unemployment and crime in England and Wales. Economics Letters, 73(1), 111-115. 